\title{
The influence of female mice age on biodistribution and biocompatibility of citrate-coated magnetic nanoparticles
}

This article was published in the following Dove Medical Press journal: International Journal of Nanomedicine

\author{
Willie O Pinheiro ${ }^{1,2}$ \\ Maria L Fascineli' \\ Gabriel R Farias' \\ Frederico H Horst' \\ Laise Rodrigues de \\ Andrade' \\ Luis Henrique Corrêa ${ }^{3}$ \\ Kelly Grace Magalhães ${ }^{3}$ \\ Marcelo Henrique Sousa ${ }^{4}$ \\ Marcos C de Almeida' \\ Ricardo B Azevedo' \\ Zulmira GM Lacava ${ }^{1,2}$ \\ 'Department of Genetics and \\ Morphology, Institute of Biological \\ Sciences, CNANO, University of \\ Brasilia, Brasilia, DF 709I0-900, \\ Brazil; ${ }^{2}$ Post-graduation Program \\ in Molecular Pathology, Faculty of \\ Medicine, University of Brasilia, \\ Brasília, DF 709/0-900, Brazil; \\ ${ }^{3}$ Laboratory of Immunology and \\ Inflammation, Department of Cell \\ Biology, University of Brasilia, \\ Brasilia, DF 709I0-900, Brazil; ${ }^{4}$ Green \\ Nanotechnology Group, Faculty \\ of Ceilandia, University of Brasilia, \\ Brasília, DF 72220-900, Brazil
}

Correspondence: Zulmira GM Lacava Department of Genetics and Morphology, Institute of Biological Sciences, CNANO, University of Brasilia, Brasília, DF

70910-900, Brazil

Tel +55 6 | 3 |07-308 |

Email zulmira@unb.br
Background: Magnetic nanoparticles (MNPs) have been successfully tested for several purposes in medical applications. However, knowledge concerning the effects of nanostructures on elderly organisms is remarkably scarce.

Purpose: To fill part of this gap, this work aimed to investigate biocompatibility and biodistribution aspects of magnetic nanoparticles coated with citrate (NpCit) in both elderly and young healthy mice.

Methods: $\mathrm{NpCit}$ (2.4 mg iron) was administered intraperitoneally, and its toxicity was evaluated for 28 days through clinical, biochemical, hematological, and histopathological examinations. In addition, its biodistribution was evaluated by spectrometric (inductively coupled plasma optical emission spectrometry) and histological methods.

Results: NpCit presented age-dependent effects, inducing very slight and temporary biochemical and hematological changes in young animals. These changes were even weaker than the effects of the aging process, especially those related to the hematological data, tumor necrosis factor alpha, and nitric oxide levels. On the other hand, NpCit showed a distinct set of results in the elderly group, sometimes reinforcing (decrease of lymphocytes and increase of monocytes) and sometimes opposing (erythrocyte parameters and cytokine levels) the aging changes. Leukocyte changes were still observed on the 28th day after treatment in the elderly group. Slight evidence of a decrease in liver and immune functions was detected in elderly mice treated or not treated with NpCit. It was noted that tissue damage or clinical changes related to aging or to the NpCit treatment were not observed. As detected for aging, the pattern of iron biodistribution was significantly different after NpCit administration: extra iron was detected until the 28th day, but in different organs of elderly (liver and kidneys) and young (spleen, liver, and lungs) mice. Conclusion: Taken together, the data show $\mathrm{NpCit} \mathrm{to} \mathrm{be} \mathrm{a} \mathrm{stable} \mathrm{and} \mathrm{reasonably} \mathrm{biocompat-}$ ible sample, especially for young mice, and thus appropriate for biomedical applications. The data showed important differences after NpCit treatment related to the animals' age, and this emphasizes the need for further studies in older animals to appropriately extend the benefits of nanotechnology to the elderly population.

Keywords: elderly, nanotoxicity, maghemite nanoparticles, superparamagnetic iron oxide nanoparticles, SPIO, nano-safety, inductively coupled plasma optical emission spectrometry, ICP-OES

\section{Introduction}

Advances in nanotechnology strongly affect biomedical applications, enabling new approaches to be developed for diagnosis and therapy. ${ }^{1}$ Several nanostructured materials are potentially useful in this area, and among these, platforms based on magnetic nanoparticles (MNPs) may be highlighted. ${ }^{2-4}$ MNPs based on iron oxides, such as 
magnetite $\left(\mathrm{Fe}_{3} \mathrm{O}_{4}\right)$ and maghemite $\left(\gamma-\mathrm{Fe}_{2} \mathrm{O}_{3}\right)$, have been widely investigated for in vivo applications because of their potential biocompatibility. To achieve the indispensable colloidal and chemical stability, ${ }^{5}$ MNPs are dispersed in a carrier solvent and coated with a stabilizing molecular layer ${ }^{6}$ provided by several different molecules, such as dextran, ${ }^{7}$ dimercaptosuccinic acid, ${ }^{8}$ polyaspartic acid, ${ }^{9}$ or citrate. ${ }^{10}$

Several MNP-based systems have succeeded in pre-clinical and clinical tests/purposes, such as delivery and controlled release of drugs to specific sites, enhancement of contrast in magnetic resonance imaging, and magnetic hyperthermia for tumor treatment. ${ }^{11-13}$ However, despite the increasing number of studies and publications related to the biomedical use of MNPs, little is known about their use in elderly organisms.

Although aging is not a disease, it is the main risk factor for chronic diseases. ${ }^{14}$ Age-related physiological, immunological, and genetic changes, associated with the concomitant presence of different diseases and possible drug interactions, make the treatment of elderly patients particularly challenging. ${ }^{15,16}$ In this context, new therapeutic strategies using MNPs may represent powerful alternatives in the treatment of age-associated diseases, like neoplasms. However, the lack of studies makes it difficult to assess nanoparticle treatments in elderly organisms.

Li et a ${ }^{17}$ emphasized that understanding the effects of nanostructure exposure on the elderly is critical, and therapies developed that are based on nanoparticle use should involve suitable animal models with special attention to nanotoxicity. In fact, the possible toxicity of MNPs is a priority in nanomedicine. ${ }^{18}$ Kaur et $\mathrm{l}^{19}$ highlighted that although the use of MNPs for therapeutic purposes, such as hyperthermia, has been announced as an important biomedical advancement, concerns about their biocompatibility need to be addressed individually for each formulation and administration, especially in elderly organisms. Besides that, some studies show under representation of elderly patients in clinical trials and, consequently, a lack of standardized treatments and clear management guidelines for these patients. ${ }^{20}$ In this context, the present work aimed to evaluate the effects of age on biocompatibility and biodistribution aspects of maghemite nanoparticles coated with citrate (NpCit) administered to elderly and young mice.

\section{Materials and methods}

\section{Synthesis and characterization of magnetic} nanoparticles coated with citrate

The NpCit sample was synthesized and kindly supplied by Dr Emilia CO Lima (UFG, Goiania, GO, Brazil). Maghemite $\left(\gamma-\mathrm{Fe}_{2} \mathrm{O}_{3}\right)$ nanoparticles were obtained via the oxidation of magnetite nanoparticles synthesized by the alkaline hydrolysis of ions $\mathrm{Fe}(\mathrm{II})$ and $\mathrm{Fe}(\mathrm{III}){ }^{21}{ }^{2} \gamma-\mathrm{Fe}_{2} \mathrm{O}_{3}$ nanoparticles were functionalized with citrate ions as described previously. ${ }^{22}$ The functionalized nanoparticles were dispersed in water, yielding stable colloidal suspension at neutral $\mathrm{pH}$. The total iron concentration in the colloidal suspension and the $\mathrm{Fe}(\mathrm{III}) / \mathrm{Fe}(\mathrm{II})$ ratio were determined by atomic absorption and colorimetric analysis, respectively. Diffraction pattern was analyzed using a Shimadzu XRD-600 diffractometer. The nanoparticle shape and size dispersity were determined by transmission electron microscopy (TEM; Jeol JEM-1011). The stability of NpCit colloidal suspension was verified through several characteristics, namely the polydispersity index (PDI), zeta potential, $\mathrm{pH}$, and hydrodynamic size, using a Zetasizer NanoZS (Malvern Instruments). The measurements were performed in triplicate, at $25^{\circ} \mathrm{C}$, with a fixed detection angle of $173^{\circ}$.

\section{Animals, NpCit treatment, and experimental design}

Elderly (E) non-isogenic Swiss mice aged 14-16 months (weighing $40 \pm 5 \mathrm{~g}$ ) and young (Y) mice aged 03-04 months (weighing $30 \pm 5 \mathrm{~g}$ ) were used. All the procedures of housing and handling of animals were carried out according to the international practices for animal use and care, after being approved by the Animal Ethics Committee of the Institute of Biological Sciences at the University of Brasilia/Brazil (CEUA, reference number 17672/2016).

A single injection of $\mathrm{NpCit}$ containing $2.4 \mathrm{mg}$ iron $(150 \mu \mathrm{L})$ was administered intraperitoneally into the animals. ${ }^{23}$ PBS was used in elderly (EC) and young (YC) control groups $(\mathrm{n}=09)$.

Biological material was collected at 1, 7, and 28 days after the NpCit injection. Elderly treated groups $(n=07)$ were accordingly named E1, E7, and E28, while young treated groups $(\mathrm{n}=05)$ were named $\mathrm{Y} 1, \mathrm{Y} 7$, and Y28. The biodistribution and biocompatibility aspects were evaluated. Comparisons of data obtained from the treated groups and the corresponding controls, as well as from the elderly and the corresponding young groups, were performed.

\section{Biocompatibility tests}

Biocompatibility evaluations of NpCit sample were performed through clinical observations (loss of weight, diarrhea, alopecia, inappetence, motor disorders, and salivary gland secretions). ${ }^{24}$ Changes in biochemical and hemogram indexes, production levels of inflammatory cytokines tumor necrosis factor alpha (TNF- $\alpha$ ) and nitric oxide (NO), and histological analyses were examined. 
All animals (elderly and young) were monitored from 2 weeks before the beginning of the experiments, and twice a week during the experimental period. The animals were weighed at the time of NpCit or PBS administration, immediately before euthanasia, and weekly in the case of groups euthanized 28 days after treatment (E28/Y28).

Biochemical analyses were performed specifically to assess hepatic, renal, tissue damage, and nutritional status due to administration of NpCit. After obtaining a total of $700 \mu \mathrm{L}$ of blood by cardiac puncture, the serum was separated by centrifugation and used for evaluations of alanine aminotransferase (ALT), aspartate aminotransferase (AST), lactate dehydrogenase (LDH), creatinine $\mathrm{K}$, urea, and albumin, using a ChemWell-T automatic biochemical analyzer (Labtest, Brazil).

Blood samples $(300 \mu \mathrm{L})$ were used for evaluating the possible effects of NpCit on the inflammatory, allergic, and anemia processes through cell count and cell type identification (leukogram, platelet, and erythrogram), using a multiple automated hematology analyzer for veterinary use, the Sysmex pocH-100iV Diff (Curitiba/Paraná, Brazil).

Effects of NpCit injection on the induction of inflammatory process were also investigated through quantification of levels of TNF- $\alpha$ in the serum of mice by the ELISA, according to the manufacturer's instructions (eBioscience and $R \& D$ System). Plates were read at $450 \mathrm{~nm}$ using a SpectraMax M3 spectrophotometer (Molecular Devices, Sunnyvale, CA, USA). In addition, measurement of NO production was detected by using Griess reagent. After incubating the plate with this reagent at room temperature, the OD was determined in a SpectraMax M3 (Molecular Devices) at a test wavelength of $540 \mathrm{~nm}$.

For analyses of morphology and acute toxicity of NpCit, the brain, spleen, liver, lungs, and kidneys were removed from elderly and young animals. Fragments of these organs were fixed in $4 \%$ buffered paraformaldehyde, dehydrated in alcohol solutions, diaphanized in xylol, and embedded in paraffin. Tissue sections $(3-5 \mu \mathrm{m})$ were stained with $\mathrm{H} \& \mathrm{E}$ and analyzed under a Zeiss Axiophot light microscope.

\section{NpCit distribution analyses}

Biodistribution aspects of NpCit nanoparticles were evaluated in two different ways: quantification of iron in the organs and histological analysis. ${ }^{25}$ After euthanasia, part of the organs (liver, spleen, lung, kidneys, and brain) and the blood were processed for determination of the amount of iron through inductively coupled plasma optical emission spectrometry (ICP-OES) using an Optima 8000 ICPOES Spectrometer. ${ }^{26}$ For histological analysis, slides were submitted to Perls' staining methods with nuclear flash red. In 3-5 $\mu \mathrm{m}$ sections, the presence of iron clusters in the tissues was detected with a Zeiss Axiophot light microscope.

\section{Statistical analyses}

Statistical analyses were performed using SPSS software version 18 and Prisma version 6.01. The normality of the continuous variables was evaluated by the Shapiro-Wilk test. Differences between the analyzed groups were investigated through ANOVA (for data following normal distribution) or Kruskal-Wallis (in the case of non-normal distribution) test. For significant results of ANOVA, pairwise comparisons were performed by Student's $t$-test or Mann-Whitney $U$ test according to the distribution of normality.

\section{Results}

\section{Nanoparticle characterization}

The characterization data of the NpCit sample are summarized in Table 1. The visual observation showed the NpCit sample to be in red-brown color, characteristic of maghemite, and absence of detectable nanoparticle precipitation, even in the presence of a magnetic field, despite the high concentration of nanoparticles $\left(18 \times 10^{18}\right.$ particles $\left./ \mathrm{mL}\right)$. Transmission electron micrographs showed $\mathrm{NpCit}$ nanoparticles with spherical-like shapes (Figure 1A). The random counting of 441 MNPs in TEM revealed a mean diameter of $10.8 \pm 2.7 \mathrm{~nm}$, as obtained by the log normal curve (Figure 1B). Measurements, especially zeta potential $(-40 \mathrm{mV})$ and PDI (0.290), indicated the high colloidal stability of the sample at $\mathrm{pH}=7 .{ }^{21}$

Table I Characterization of the maghemite $\left(\gamma-\mathrm{Fe}_{2} \mathrm{O}_{3}\right)$ nanoparticles functionalized with citrate ions ( $\mathrm{NpCit}$ ) and the magnetic colloidal suspension

\begin{tabular}{|l|l|}
\hline NpCit or colloidal suspension features & Evaluation \\
\hline Maghemite molecular formula & $\gamma-\mathrm{Fe}_{2} \mathrm{O}_{3}{ }^{*}$ \\
\hline Mean diameter by XRD & $8 \mathrm{~nm}$ \\
\hline Mean diameter by TEM & $10.8 \mathrm{~nm}$ \\
\hline MNP shape & Spherical \\
\hline Hydrodynamic diameter & $78.40 \mathrm{~nm}$ \\
\hline PDI (polydispersity index) & 0.290 \\
\hline Zeta potential & $-40 \mathrm{mV}$ \\
\hline Iron concentration by atomic absorption & $16.0 \mathrm{mg} / \mathrm{mL}$ \\
\hline Nanoparticle concentration & $18 \times 10^{18}$ particles $/ \mathrm{mL}$ \\
\hline Color & Red-brown \\
\hline pH & 7.3 \\
\hline
\end{tabular}

Note: *The crystalline phase of the nanoparticles was characterized as maghemite based on the $\mathrm{Fe}(\mathrm{III}) / \mathrm{Fe}(\mathrm{II})$ ratio and the diffraction pattern characteristic of cubic spinel. Abbreviations: XRD, X-ray diffractometry; TEM, transmission electron microscopy; MNP, magnetic nanoparticle. 
A

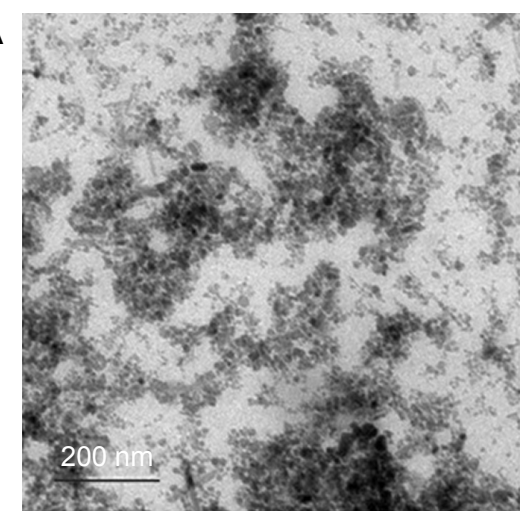

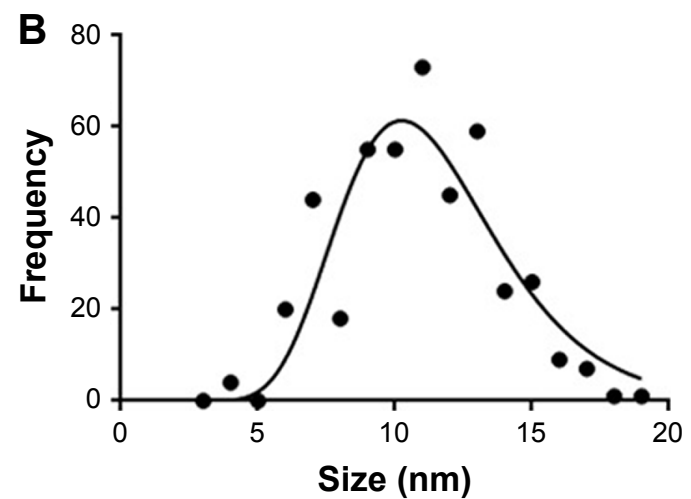

Figure I (A) TEM micrograph (scale bar: $200 \mathrm{~nm}$ ) and (B) histogram of MNP size distribution. Abbreviations: TEM, transmission electron microscopy; MNP, magnetic nanoparticle.

\section{Biocompatibility evaluation}

The intraperitoneal treatment of mice with NpCit sample ( $2.4 \mathrm{mg}$ iron) did not induce obvious clinical or behavioral changes such as hair loss, diarrhea, inappetence, salivary gland secretions, and motor dysfunction throughout the entire experimental period in all elderly and young animals investigated. Further, NpCit did not induce significant variation in the animal weight in elderly and young treated groups when compared to their corresponding controls.

The biochemical analyses (Table 2) showed through comparisons with non-treated controls that elderly animals (EC) presented lesser amounts of ALT and albumin than young animals (YC). However, the administration of NpCit induced different effects in elderly and young animals. In the elderly group, a temporary significant decrease in the urea and an increase in the albumin levels were observed at day 1 after $\mathrm{NpCit}$ treatment (E1) in comparison to the control (EC). Levels of the enzymes AST, creatinine K, ALT, and LDH were not significantly different in all the treated elderly groups (E1, E7, and E28) compared to EC, at any point of time.

In the young animals, $\mathrm{NpCit}$ administration caused significant decreases in urea, albumin, and LDH levels at day 7 after NpCit injection (Y7) compared to the YC group. In this group, NpCit did not cause alterations in the ALT, AST, and creatinine $\mathrm{K}$ levels in all treated young groups (Y1, Y7, and Y28) compared to the control (YC).

The leukogram analysis (Table 3) showed, through comparisons between the elderly groups and their corresponding

Table 2 Biochemical analysis of the elderly and young mice after treatment with NpCit (2.4 mg iron)

\begin{tabular}{|c|c|c|c|c|c|c|}
\hline Groups & $\begin{array}{l}\text { ALT } \\
(U / L)\end{array}$ & $\begin{array}{l}\text { AST } \\
(U / L)\end{array}$ & $\begin{array}{l}\text { Creatinine K } \\
(\mathrm{mg} / \mathrm{dL})\end{array}$ & $\begin{array}{l}\text { Urea } \\
(\mathrm{mg} / \mathrm{dL})\end{array}$ & $\begin{array}{l}\text { Albumin } \\
(\mathrm{g} / \mathrm{dL})\end{array}$ & $\begin{array}{l}\text { LDH } \\
\text { (mg/dL) }\end{array}$ \\
\hline \multicolumn{7}{|l|}{ Elderly } \\
\hline EC & $50 \pm 20$ & $203.3 \pm 125.4$ & $0.38 \pm 0.28$ & $50.9 \pm 14.2$ & $1.8 \pm 0.2$ & $2,159.4 \pm 1,101.1$ \\
\hline EI & $63.3 \pm 66.2$ & $166 \pm 105.2$ & $0.32 \pm 0.07$ & $39.0 \pm 7.8^{*, E C}$ & $\mathbf{2 . 2} \pm \mathbf{0 . 3} \mathbf{3}^{* \mathrm{EC}}$ & $1,427.9 \pm 891.9$ \\
\hline E7 & $50 \pm 16.7$ & $246.33 \pm 204.33$ & $0.30 \pm 0.07$ & $45.8 \pm 9.3$ & $1.7 \pm 0.2$ & $2,072.5 \pm 497.9$ \\
\hline E28 & $78 . \pm 52.5$ & $|7| .7 \mid \pm 93.68$ & $0.42 \pm 0.19$ & $55 \pm 24.1$ & $1.6 \pm 0.8$ & $\mathrm{I}, 840.7 \pm 1,213.0$ \\
\hline$P$-value & 0.6121 & 0.6286 & 0.4333 & 0.0450 & 0.0131 & 0.5158 \\
\hline \multicolumn{7}{|l|}{ Young } \\
\hline YC & $98.4 \pm 97 *, \mathrm{EC}$ & $193 \pm 127.42$ & $0.38 \pm 0.02$ & $42.6 \pm 5.5$ & $\mathbf{2 . 7} \pm \mathbf{0 . 6} \mathbf{6}^{*, \mathrm{EC}}$ & $2,373.9 \pm 1,556.7$ \\
\hline YI & $81.8 \pm 73.8$ & $146 \pm 1 \mid 2.57$ & $0.29 \pm 0.14$ & $43.4 \pm 10.5$ & $2.6 \pm 0.4$ & $2,127.4 \pm 2,249.3$ \\
\hline Y7 & $46.6 \pm 31.0$ & $174.2 \pm 141.3$ & $0.49 \pm 0.4 \mathrm{I}$ & $37.2 \pm 4 . I^{*}, \mathrm{YC}$ & $\mathbf{2 . 2} \pm \mathbf{0 .} \mathbf{I}^{*, \mathrm{E} 7}$ & $941.8 \pm 634.3^{* *, E 7}$ \\
\hline Y28 & $63.8 \pm 59.5$ & $189.5 \pm 109.4$ & $0.47 \pm 0.33$ & $44.3 \pm 12.5$ & $\mathbf{2 . 2} \pm \mathbf{0 . 5} \mathbf{5}^{*, \mathrm{E} 28}$ & $1,508.3 \pm 819.7$ \\
\hline$P$-value & 0.4436 & 0.9201 & 0.6739 & 0.0499 & 0.1056 & 0.4616 \\
\hline
\end{tabular}

Notes: Data were expressed as mean \pm SD. Data significantly different $(* P<0.05)$ or highly significant $(* * P<0.0$ I) between groups were detected by Student's $t$-test or MannWhitney $U$ test and are indicated by asterisks followed by superscript bold letters. Significant $P$-values $(P<0.0500)$ among the group animals were generated by ANOVA or Kruskal-Wallis and are indicated by bold numbers.

Abbreviations: NpCit, nanoparticles coated with citrate; ALT, alanine aminotransferase; AST, aspartate aminotransferase; LDH, lactate dehydrogenase; EC, elderly control; $\mathrm{EI}, \mathrm{E7}$, and E28, elderly groups investigated at day 0I, day 07, and day 28 after NpCit treatment, respectively; YC, young control; YI, Y7, and Y28, young treated groups investigated at day $0 \mathrm{I}$, day 07 , and day 28 , respectively. 
Table 3 Effects of $\mathrm{NpCit} \mathrm{(2.4} \mathrm{mg} \mathrm{iron)} \mathrm{treatment} \mathrm{on} \mathrm{the} \mathrm{leukogram} \mathrm{and} \mathrm{platelet} \mathrm{parameters} \mathrm{of} \mathrm{elderly} \mathrm{and} \mathrm{young} \mathrm{mice}$

\begin{tabular}{|c|c|c|c|c|c|c|c|}
\hline & $\begin{array}{l}\text { WBC } \\
\left(10^{3} / \mu L\right)\end{array}$ & $\begin{array}{l}\text { W-SCR } \\
\text { (\%) }\end{array}$ & $\begin{array}{l}\text { W-MCR } \\
\text { (\%) }\end{array}$ & $\begin{array}{l}\text { W-LCR } \\
\text { (\%) }\end{array}$ & $\begin{array}{l}\text { W-SCC } \\
\left(10^{3} / \mu L\right)\end{array}$ & $\begin{array}{l}\text { W-MCC } \\
\left(10^{3} / \mu L\right)\end{array}$ & $\begin{array}{l}\text { PLT } \\
\left(10^{3} / \mu L\right)\end{array}$ \\
\hline \multicolumn{8}{|l|}{ Elderly } \\
\hline EC & $3.4 \pm 2.2$ & $55.0 \pm 12.7$ & $41.6 \pm 12.5$ & $3.4 \pm 3.2$ & $1.7 \pm 0.8$ & $1.5 \pm 1.2$ & $941.4 \pm 364.2$ \\
\hline EI & $3.5 \pm 1.5$ & $41.7 \pm 12.5 *$,EC & $57.1 \pm \mid 2.9^{*, E C}$ & $1.3 \pm 1.2$ & $1.5 \pm 0.8$ & $2.0 \pm 0.9$ & $1,211.7 \pm 492.7$ \\
\hline E7 & $3.9 \pm 2.2$ & $54.3 \pm 14.9$ & $40.9 \pm 14.1$ & $4.8 \pm 4.4$ & $1.9 \pm 0.7$ & $1.8 \pm 14$ & $1,169 \pm 215.4$ \\
\hline E28 & $4.6 \pm 4.8$ & 44. $I \pm 7.9^{*, \mathrm{EC}}$ & $54.1 \pm 7.7^{*, \mathrm{EC}}$ & $1.9 \pm 0.8$ & $2.1 \pm 2.7$ & $2.3 \pm 2$ & I, $364.4 \pm 568.3$ \\
\hline$P$-value & 0.9631 & 0.0480 & 0.0306 & 0.2290 & 0.7146 & 0.7434 & 0.1590 \\
\hline \multicolumn{8}{|l|}{ Young } \\
\hline YC & $4.6 \pm 2.6$ & $80.3 \pm 5.3 * *, \mathrm{EC}$ & $17.7 \pm 4.0 * *, \mathrm{EC}$ & $2.3 \pm 2.4$ & $3.7 \pm 2.2^{* . \mathrm{EC}}$ & $0.8 \pm 0.4$ & $1,040.9 \pm 269.2$ \\
\hline YI & $4.3 \pm 1.8$ & $76.7 \pm 7.9^{* *, \mathrm{EI}}$ & $20.7 \pm 6.1 * *, \mathrm{EI}$ & $2.6 \pm 2.6$ & $3.2 \pm I .2^{*, \mathrm{EI}}$ & $0.9 \pm 0.6 *$ EI & $732.8 \pm 45 I .4$ \\
\hline Y7 & $3.6 \pm 0.5$ & $77.3 \pm 8.9 * . E 7$ & $21.3 \pm 7.4^{*, \mathrm{E} 7}$ & $1.4 \pm 1.7$ & $2.8 \pm 0.2^{*, E 7}$ & $0.8 \pm 0.4$ & 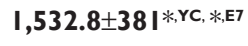 \\
\hline Y28 & $4.8 \pm 2$ & $75.2 \pm 7.6 * *, E 28$ & $21.7 \pm 5.7^{* *, E 28}$ & $3.0 \pm 3.1$ & $3.6 \pm I .0^{*, E 28}$ & $1.1 \pm 0.5$ & $907.6 \pm 327.2$ \\
\hline$P$-value & 0.5962 & 0.6126 & 0.5216 & 0.7280 & 0.5799 & 0.7072 & 0.0255 \\
\hline
\end{tabular}

Notes: Data were expressed as mean \pm SD. Data significantly different $(* P<0.05)$ or highly significant $(* * P<0.01)$ between groups were detected by Student's $t$-test or MannWhitney $U$ test and are indicated by asterisks followed by superscript bold letters. Significant $P$-values $(P<0.0500)$ among the group animals were generated by ANOVA or Kruskal-Wallis and are indicated by bold numbers.

Abbreviations: NpCit, nanoparticles coated with citrate; WBC, total leukocyte count; W-SCR, small cell rate (lymphocytes); W-MCR, mean cell rate (basophils, eosinophils, and monocytes); W-LCR, rate of large cells (neutrophils); W-SCC, absolute small cell count (lymphocytes); W-MCC, absolute count of medium cells (basophils, eosinophils, and monocytes); PLT, platelets; EC, elderly control; EI, E7, and E28, elderly groups investigated at day 0I, day 07, and day 28 after NpCit treatment, respectively; YC, young control; $Y 1, Y 7$, and $Y 28$, young treated groups investigated at day $0 \mathrm{I}$, day 07 , and day 28 , respectively.

young groups, that the elderly animal groups EC, E1, E7, and E28 presented significant decreases in the rate of lymphocytes (small cell rate [lymphocytes], W-SCR) and in the absolute counting of lymphocytes (absolute small cell count [lymphocytes], W-SCC) when compared to YC, Y1, $\mathrm{Y} 7$, and Y28, respectively. In addition, the same elderly groups showed significant increases in the mean cell rates of basophils, eosinophils, and monocytes (W-MCR), when compared to the young groups.

In the elderly groups, the $\mathrm{NpCit}$ treatment induced significant decreases in the rate of lymphocytes (W-SCR) observed in the day 1 group (E1) and in the day 28 group (E28) compared to the EC group. In contrast, significant increases in the mean cell rate (basophils, eosinophils, and monocytes) were also observed in groups E1 and E28, compared to EC.

In the young groups (Y1, Y7, and Y28), different from the elderly groups, NpCit did not induce any significant alterations in the leukocyte parameters as compared to the control young group (YC).

Regarding platelets, significant differences were not found either in comparison between the control elderly and young groups, or in comparison of NpCit-treated elderly animals with the control elderly mice (Table 3 ). The only significant alterations in platelet count were observed in the young group at day 7 (Y7) in comparison with both the control young animals (YC) and the treated elderly animals, also at day 7 (E7).
The erythrogram analysis (Table 4) revealed that the aging process caused significant alterations in most of the parameters investigated. In fact, the elderly groups in comparison to their corresponding young groups showed significant decreases in the total erythrocyte counts (RBC) for E1, E7, and E28 groups compared to their corresponding young groups Y1, Y7, and Y28. Besides, significant decreases in the hemoglobin (HGB) concentration, mean corpuscular volume, and hematocrit values were observed for EC, E1, E7, and E28 compared to YC, Y1, Y7, and Y28 groups, respectively. On the other hand, mean corpuscular hemoglobin was significantly higher in EC group than in YC group, while the red cell distribution width was higher in EC, $\mathrm{E} 1$, and $\mathrm{E} 28$ than in $\mathrm{YC}, \mathrm{Y} 1$, and $\mathrm{Y} 28$ groups, respectively (Table 4).

Concerning the pro-inflammatory cytokines, NpCit administration in elderly mice triggered a decrease in TNF- $\alpha$ levels at day 7 (E7) compared to the untreated mice (EC). There was also a significant decrease of TNF- $\alpha$ levels in young mice submitted to NpCit administration at day 7 (Y7) compared to the corresponding elderly mice (E7), as shown in Figure 2A. Moreover, there was a decrease in NO levels in the serum of untreated control elderly mice (EC) and treated young mice at day 1 (Y1), when both groups were compared to control young mice (YC) (Figure 2B).

The histological analysis of tissues after H\&E staining showed no abnormalities in all tissues analyzed for both 
Table 4 Erythrogram analysis of the elderly and young mice observed at different time points after NpCit (2.4 mg iron) administration

\begin{tabular}{|c|c|c|c|c|c|c|c|}
\hline & $\begin{array}{l}\text { RBC } \\
\left(10^{6} / \mu \mathrm{L}\right)\end{array}$ & $\begin{array}{l}\text { HGB } \\
(\mathrm{g} / \mathrm{dL})\end{array}$ & $\begin{array}{l}\text { HCT } \\
\text { (\%) }\end{array}$ & $\begin{array}{l}\text { MCV } \\
\text { (fL) }\end{array}$ & $\begin{array}{l}\mathrm{MCH} \\
\text { (pg) }\end{array}$ & $\begin{array}{l}\text { MCHC } \\
\text { (g/dL) }\end{array}$ & $\begin{array}{l}\text { RDW-CV } \\
\text { (\%) }\end{array}$ \\
\hline \multicolumn{8}{|l|}{ Elderly } \\
\hline EC & $7.1 \pm 1.8$ & $10.5 \pm 2.3$ & $27.2 \pm 6.2$ & $38.5 \pm 1.4$ & $14.8 \pm 0.4$ & $38.6 \pm 0.9$ & $15.4 \pm 2.1$ \\
\hline EI & $7.8 \pm I . I$ & $11.5 \pm 1.6$ & $29.9 \pm 4.5$ & $38.5 \pm 0.6$ & $14.9 \pm 0.5$ & $38.6 \pm I .1$ & $15.6 \pm 1.8$ \\
\hline E7 & $8.2 \pm 0.3$ & $12.0 \pm 0.5$ & $31.2 \pm 1.5$ & $38 \pm 0.8$ & $14.6 \pm 0.5$ & $38.4 \pm 1.2$ & $15.0 \pm 1.2$ \\
\hline E28 & $7.3 \pm 1.0$ & $10.06 \pm 1.4$ & $28.1 \pm 3.6$ & $38.4 \pm 1.3$ & $14.5 \pm 0.6$ & $37.8 \pm 1.0$ & $16.2 \pm 1.9$ \\
\hline$P$-value & 0.3632 & 0.3705 & 0.3976 & 0.8602 & $0.448 I$ & 0.4626 & 0.6655 \\
\hline \multicolumn{8}{|l|}{ Young } \\
\hline YC & $9.2 \pm 1.1$ & I $3.0 \pm \mathrm{I} .4^{*, \mathrm{EC}}$ & $33.6 \pm 3.9 *, \mathrm{EC}$ & $\mathbf{3 6 . 6} \pm 0.4 * *, \mathrm{EC}$ & $14.2 \pm 0.3^{* *, E C}$ & $38.8 \pm 0.7$ & $13.6 \pm 1.3^{*, E C}$ \\
\hline YI & $9.1 \pm 0.7^{*, E I}$ & $13.2 \pm 1.2^{*, \mathrm{EI}}$ & $33.6 \pm 3.2$ & $37.1 \pm 0.9^{*, E I}$ & $14.6 \pm 0.3^{*, \mathrm{YC}}$ & $39.4 \pm 0.5$ & $\mid 3.4 \pm 0.3^{* *, E \mid}$ \\
\hline Y7 & $9.9 \pm 0 . I^{*, \mathrm{E} 7}$ & $14.0 \pm 0.3^{* *, E 7}$ & $36.0 \pm 0.4^{* *, E 7}$ & $36.5 \pm 0.5^{*, E 7}$ & $14.2 \pm 0.3$ & $38.5 \pm 0.4$ & $14.3 \pm 0.8$ \\
\hline $\mathrm{Y} 28$ & $9.2 \pm 0.9 * *, \mathrm{E} 28$ & $|3.| \pm\left.\right|^{*, E 28}$ & $33.72 \pm 3.2^{*, E 28}$ & $36.8 \pm 0.5^{*, E 28}$ & $14.2 \pm 0.3$ & $38.8 \pm 0.4$ & $13.8 \pm 0.5^{*, E 28}$ \\
\hline$P$-value & 0.2299 & 0.4546 & 0.3745 & 0.6033 & $0.048 I$ & 0.0678 & 0.1601 \\
\hline
\end{tabular}

Notes: Data were expressed as mean \pm SD. Data significantly different $(* P<0.05)$ or highly significant $(* * P<0.01)$ between groups were detected by Student's $t$-test or MannWhitney $U$ test and are indicated by asterisks followed by superscript bold letters. Significant $P$-values $(P<0.0500)$ among the group animals were generated by ANOVA or Kruskal-Wallis and are indicated by bold numbers.

Abbreviations: NpCit, nanoparticles coated with citrate; RBC, red blood cells; HGB, hemoglobin; HCT, hematocrit; MCV, mean corpuscular volume; MCH, mean corpuscular hemoglobin; $\mathrm{MCHC}$, mean corpuscular hemoglobin concentration; RDW-CV, red blood cell distribution width as coefficient of variation; EC, elderly control; $\mathrm{EI}, \mathrm{E7}$, and E28, elderly groups investigated at day 0I, day 07, and day 28 after NpCit treatment, respectively; YC, young control; YI, Y7, and Y28, young treated groups investigated at day $0 \mathrm{I}$, day 07 , and day 28 , respectively.

young and elderly animals, treated or not treated with $\mathrm{NpCit}$ sample (data not shown). Briefly, the brains had no pathologies in the white and gray matter; in the spleens, both red and white pulps were easily distinguishable and there were no large numbers of white cells; the observed livers presented hepatocytes in polyhedral shape, radiating from a central vein; in the lungs, there were no signs of fibrosis; and in the kidneys, cells from glomerulus, proximal, and distal convoluted tubules presented normal patterns.

\section{NpCit biodistribution}

The NpCit biodistribution assays in the organs and blood performed by ICP-OES are shown in Figure 3. Comparisons between $\mathrm{EC}$ and $\mathrm{YC}$ animals showed that although the amount of iron in the blood was similar in both groups (Figure 3A), the spleen, liver, kidney, lung, and brain presented a significantly higher concentration of iron in the elderly group (Figure 3B-F) than in the young group.

In fact, the distribution of iron in both animal groups was also different; while the EC group presented the iron in descending order, spleen $>$ blood $>$ liver $>$ kidney $>$ lung $>$ brain, in the YC mice, the order was blood $>$ spleen $>$ liver $>$ lung $>$ kidney $>$ brain.

Concerning the effects induced by $\mathrm{NpCit}$ in the elderly groups, there were significant changes in comparison with the control untreated mice: an increase of iron levels in the blood and decrease in the kidneys at day 1 and an increase in the liver at day 28. The significant effects of $\mathrm{NpCit}$ on the
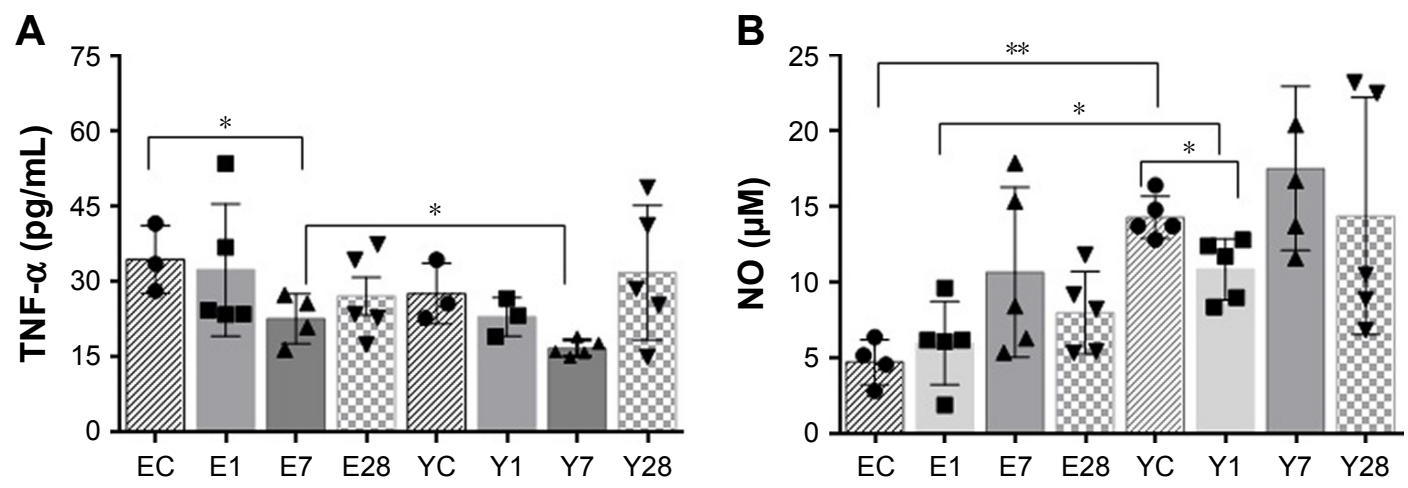

Figure 2 Effects of NpCit (2.4 mg iron) injection on the TNF- $\alpha$ and NO levels in serum of elderly and young mice.

Notes: $(\mathbf{A})$ TNF- $\alpha$ levels were detected by ELISA and $(\mathbf{B})$ NO levels were detected by Griess assay. Asterisks indicate significant $(* P<0.05)$ and highly significant $(* * P<0.01)$ differences.

Abbreviations: $\mathrm{NpCit}$, nanoparticles coated with citrate; TNF- $\alpha$, tumor necrosis factor alpha; NO, nitric oxide; EC, elderly control; EI, E7, and E28, elderly groups investigated at day $0 \mathrm{I}$, day 07 , and day 28 after $\mathrm{NpCit}$ treatment, respectively; YC, young control; YI, Y7, and Y28, young treated groups investigated at day $0 \mathrm{I}$, day 07 , and day 28 , respectively. 

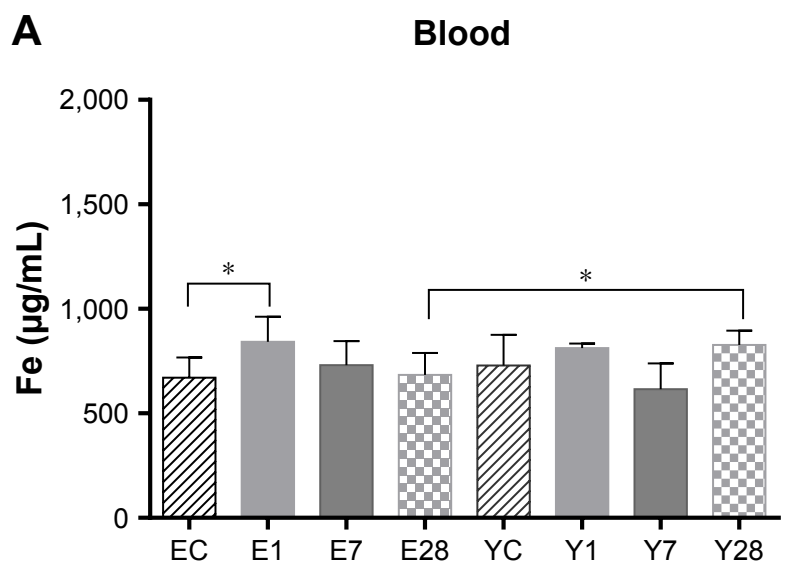

C

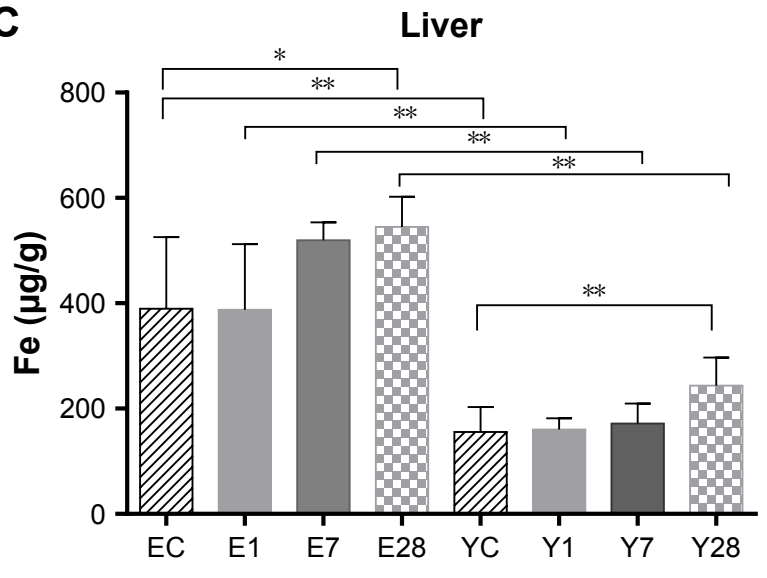

$\mathbf{E}$

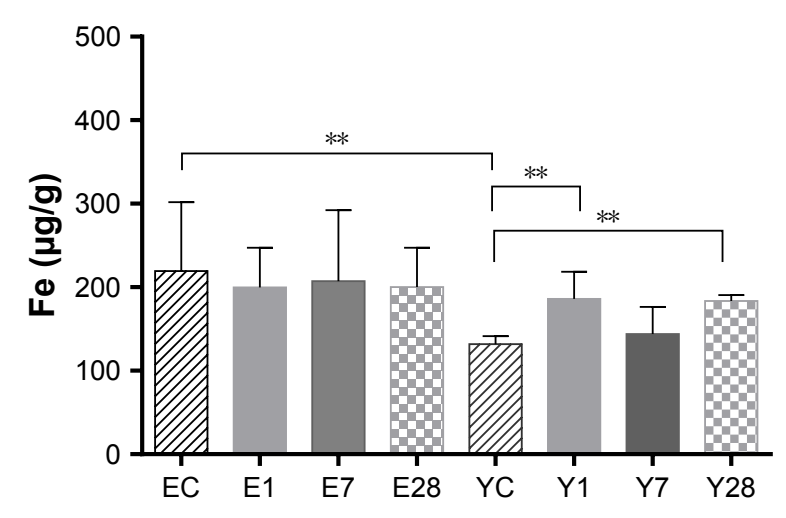

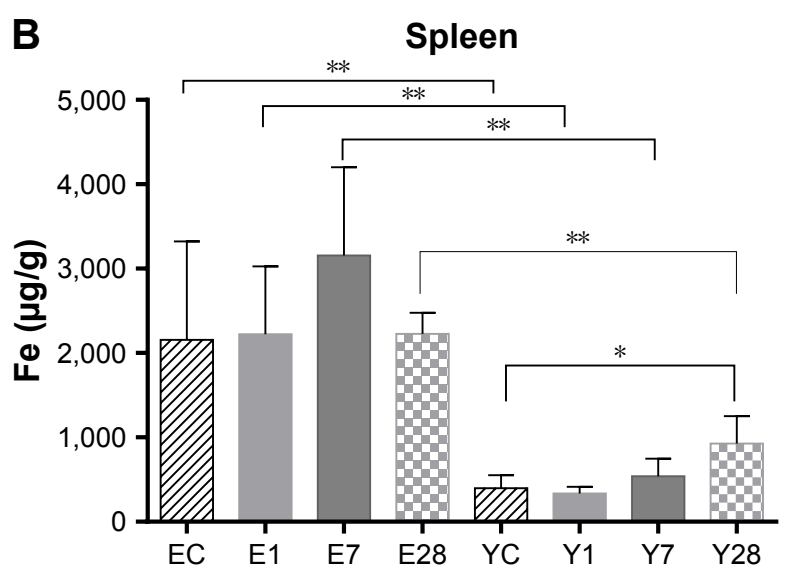

D

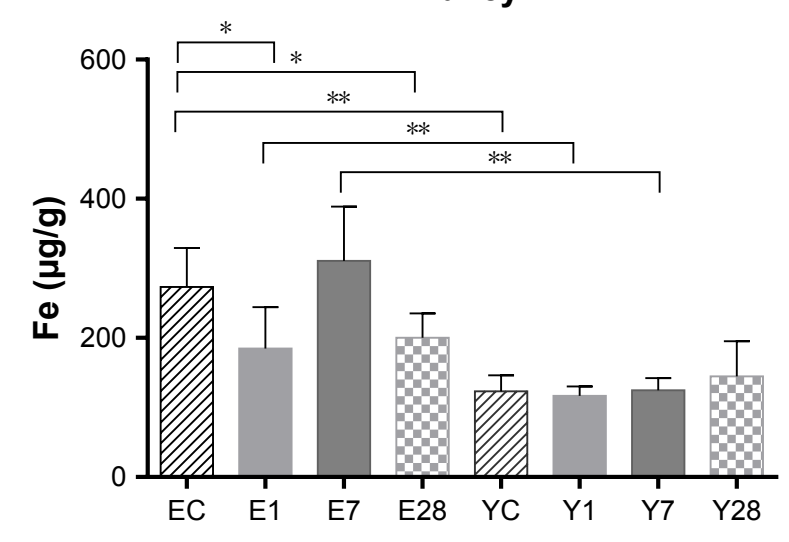

$\mathbf{F}$

Brain

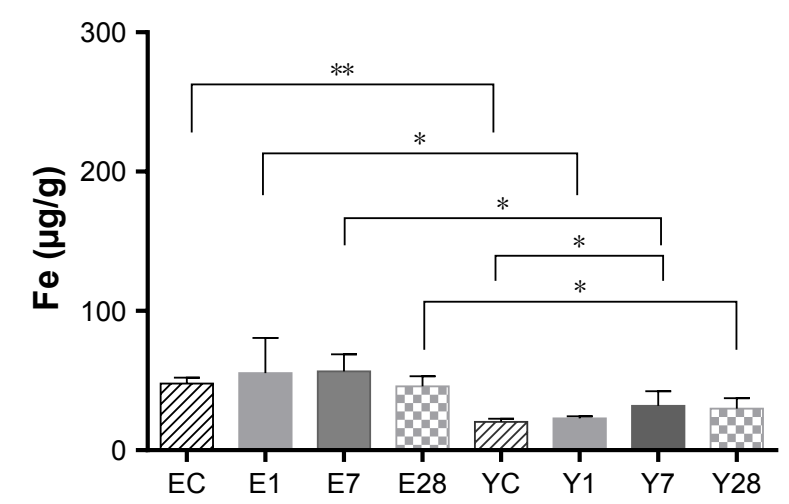

Figure 3 Biodistribution of iron as obtained by inductively coupled plasma optical emission spectrometry (ICP-OES).

Notes: Concentration of iron in the blood $(\mu \mathrm{g} / \mathrm{mL})(\mathbf{A})$ and in the organs $(\mu \mathrm{g} / \mathrm{g})$ in decreasing order from spleen to brain $(\mathbf{B}-\mathbf{F})$. Asterisks indicate significant $(* P<0.05)$ and highly significant $(* * P<0.01)$ differences.

Abbreviations: EC, elderly control; EI, E7, and E28, elderly groups investigated at day 0I, day 07, and day 28 after $\mathrm{NpCit}$ treatment, respectively; YC, young control; $\mathrm{YI}, \mathrm{Y} 7$, and $\mathrm{Y} 28$, young treated groups investigated at day $0 \mathrm{I}$, day 07 , and day 28 , respectively.

young treated groups when compared to the $\mathrm{YC}$ group were different from the elderly groups and characterized by iron level increases in the lungs at day 1 , in the brain at day 7 , and in the spleen, liver, and lungs at day 28.

Due to the initial differences in the amount of iron between elderly and young groups, the comparison of elderly treated animals (E1, E7, and E28) with the corresponding young treated groups (Y1, Y7, and Y28) led to significant differences, particularly in the spleen, liver, and brain, as shown in Figure 3.

Through microscopic observation after Perls' staining (Figure 4), it was possible to observe iron aggregates in 


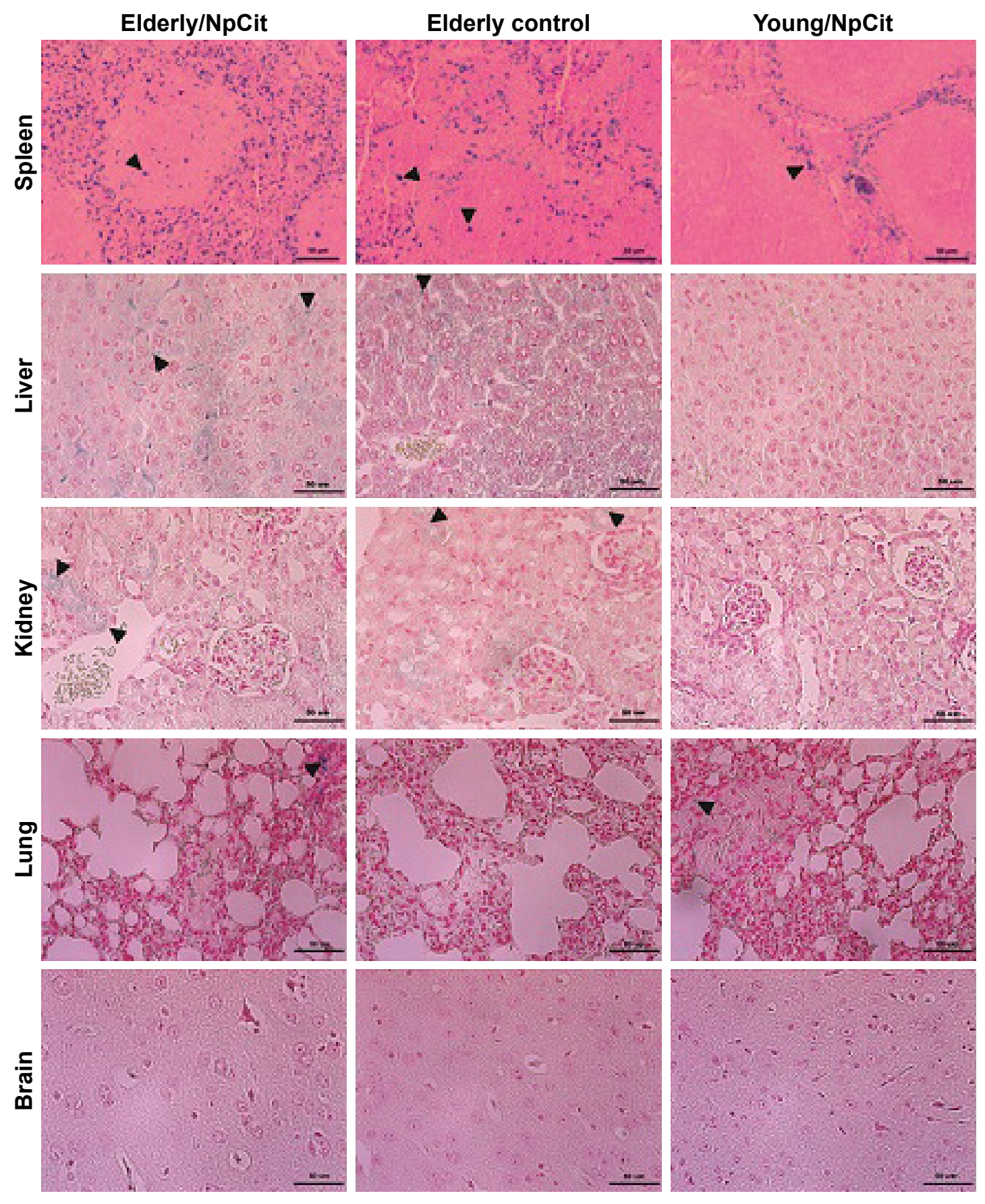

Figure 4 Effects of $\mathrm{NpCit}$ on iron distribution of elderly (left column) and young (right column) animals. Organ sections of elderly control animals without treatment are presented in the central column. Histological sections of spleen, liver, kidneys, lungs, and brain were submitted to Perls' blue staining. Arrows indicate blue positive aggregates which are more evident in the spleen. Micrographs are illustrative and were taken at day 7 and day 28 of treatment, respectively, from elderly and young animals. Scale bar $=50 \mu \mathrm{m}$.

Abbreviation: $\mathrm{NpCit,} \mathrm{nanoparticles} \mathrm{coated} \mathrm{with} \mathrm{citrate.}$

all the analyzed organs, except in the brain. In general, the concentration was higher in the elderly animals than in the young animals, in both NpCit treated and control groups. The highest iron concentration was observed in the spleen of elderly mice of the day 7 group. In this group, the iron concentration was higher than in the EC group or the corresponding young group (Y7). In the young groups, highest concentrations in the spleen were observed at day 28 .

To facilitate the comparison between the effects related to aging and/or the NpCit treatment, a table containing a summary of the main effects of aging and/or NpCit treatment in mice is presented (Table S1). 


\section{Discussion}

This work was performed to compare the effects of citratecoated MNPs on healthy elderly and young mice, focusing on biocompatibility and biodistribution aspects. Citrate is a biocompatible small molecule that has been widely accepted as the capping agent to stabilize water-dispersible MNPs for biomedical applications, and it is even commercially available. This is attributed to the fact that citrate is capable of adsorption onto the surface of MNPs (especially iron oxides) by coordinating via one or two carboxylate groups, leaving at least one carboxylate group exposed to the bulk medium. This makes the nanoparticle surface hydrophilic, negatively charged in a wide range of $\mathrm{pH}$ (including the physiological one), and cytocompatible, preventing particle agglomeration and providing functional groups to be used for further surface modification. Moreover, citrate detachment from the surface of MNPs under physiological conditions is negligible, and the physical-chemical characteristics of citrate-capped MNPs can be preserved over years. ${ }^{21,27}$ Indeed, previous in vivo investigations have shown the biocompatibility and nonmutagenic effects of citrate coatings, ${ }^{28-30}$ in spite of adverse effects described in in vitro tests. ${ }^{31}$

However, citrate-coated MNPs can be colloidally unstable in a biological system when dispersed in a medium with high ionic strength, such as PBS buffer. Sharma et al ${ }^{32}$ reported coagulation of citrate-stabilized iron oxide particles in PBS, a high increase of the hydrodynamic diameter ( $>15$-fold), and formation of precipitates. To avoid this undesirable effect, in our work, dilution/dispersion of citratecapped MNPs was performed in water (ie, low ionic strength medium). Therefore, zeta potential $(-40 \mathrm{mV})$, hydrodynamic size $(\sim 78 \mathrm{~nm})$, and PDI (0.290) indicated the high colloidal stability of diluted $\mathrm{NpCit} \mathrm{samples} \mathrm{at} \mathrm{pH}=7$.

Szigeti et $\mathrm{al}^{27}$ showed that citric acid as a surface-capping agent to control size and biocompatibility and to avoid agglomeration of the synthesized particles is able to chelate $\mathrm{Ca}^{2+}$ ions. However, physiological $\mathrm{Ca}^{2+}$ concentration does not affect in vivo colloidal properties. The authors affirm that at the physiological $\mathrm{pH}$ of 7.4, the zeta potential of citrate-coated MNPs and the steric stabilization effect of citrate coating further enhance the colloidal stability. Thus, even if there are other ions in addition to $\mathrm{Ca}^{2+}$ and other complexing molecules, the citrate-coated samples present considerable biological stability and thus suitability for use in in vivo tests..$^{27,33,34}$

Concerning the in vivo biocompatibility tests, differences related to the aging process and some significant changes induced by the NpCit sample were observed. Liver and renal functions represent important predictors of toxicity and aging. Dysfunctions in the hepatobiliary system represent more than $50 \%$ of toxicity events occasioned by chemical agents. ${ }^{35}$ These are traditionally assessed by measuring the serum levels of AST and ALT. ${ }^{36,37}$ AST is widely distributed in the organism ${ }^{38}$ and was not altered by mice aging or after NpCit treatment, suggesting no damage in the cytoplasmic and mitochondrial membranes. ${ }^{36}$ In accordance with this, the administration of NpCit did not induce changes in the ALT enzyme levels of young or elderly animals, despite the presence of higher levels of iron in the liver. However, ALT which is usually produced in high concentrations in the liver presented a twofold reduction in the EC animals, thus indicating possible liver cell lesions in this group ${ }^{38-41}$ with a subsequent decrease in the mitochondrial number, ${ }^{14}$ an aging characteristic not detected in this study.

Kidney function was evaluated by serum creatinine and urea levels. ${ }^{37}$ The absence of creatinine level changes that are related to aging or NpCit treatment is indicative of preserved kidney function. ${ }^{42,43}$ Indeed, no increase was observed in serum urea, which may derive from a decreased glomerular filtration ${ }^{37}$ related to aging or nephrotoxicity. On the other hand, a decrease in serum urea may be associated with liver impairment, since this organ is responsible for the production of urea during protein catabolism. ${ }^{42} \mathrm{NpCit} \mathrm{led} \mathrm{to} \mathrm{a} \mathrm{reduction} \mathrm{of} \mathrm{urea} \mathrm{levels} \mathrm{in}$ both elderly and young animals, but this effect was temporary and not observed at the 28th day after treatment, even if the iron concentration was still higher than usual at this time.

Other biochemical changes were investigated through albumin and LDH levels. Albumin is an abundant serum protein produced in the liver. ${ }^{44}$ In this study, the albumin level in elderly animals appeared lower than in young animals, another sign of possible kidney or liver dysfunction consistent with the aging process. However, no significant differences in the LDH enzyme levels were observed between elderly and young groups, nor were they seen after NpCit treatment, indicating once again that there was no damage to the body's tissues or any production of excessive free radicals related to the NpCit treatment or even to aging.

The hemogram analysis showed the predominance of myeloid cells in the elderly group and higher lymphoid cells in the young group, considered a hallmark difference between elderly and young mice..$^{45}$ Lymphocytes are crucial for the immune response, ${ }^{42}$ and the decrease in lymphocytedependent immunity could increase oxidative stress and foment diseases related to aging. ${ }^{46}$ Remarkably, these differences were even more pronounced and durable after $\mathrm{NpCit}$ 
treatment of elderly mice. At the same time, NpCit did not affect leukocyte populations in young groups, evidencing one important aspect of nanoparticle applications to be taken into account in older organisms. On the other hand, myeloid cells are responsible for the phagocytosis of foreign particles, and their increase in the elderly group could explain why the increase of iron in the blood was observed only on the first day after the NpCit injection. Interestingly, erythrogram differences were essentially only related to the aging process.

The pro-inflammatory cytokine TNF- $\alpha$ may be associated with the triggering mechanisms of typical age-related diseases and inflammatory processes ${ }^{47}$ Accordingly, a tendency to having a higher level of TNF- $\alpha$ was observed in the EC group. Nevertheless, significant TNF- $\alpha$ decreases were temporarily induced 7 days after NpCit treatment. The other cytokine investigated, NO, was also modulated after the NpCit injection. NO is involved in many physiological and pathological processes and can have opposite actions such as damage or protection of cells during inflammatory response. ${ }^{48}$ In this study, NO levels in the elderly mice were lower than in the young mice, despite a higher number of phagocytes observed in the elderly animals, whether they were treated or not with NpCit. ${ }^{48}$ Low levels of NO production are typically involved in liver damage, and they can enhance the risk of several diseases associated with older individuals, which was not evidenced by biochemical data. In addition, although $\mathrm{NpCit}$ did not affect NO production in the elderly mice, it induced a temporary significant reduction of NO levels in young mice 1 day after the treatment. In a previous study, the NP-induced neurotoxicity was correlated with the increase of NO production, ${ }^{34}$ indicating that different NP samples may have diverse actions in organisms.

The findings that the effects induced by $\mathrm{NpCit}$ in the young group were slight and no longer observed after the seventh day after treatment suggest the biocompatibility of the sample. This supposition is strongly supported by both the absence of histological alterations in all the organs investigated and absence of clinical changes usually associated with aging or toxicity. ${ }^{24}$ It is reasonable to extend this conclusion to the elderly mice, but since they still presented some leukocyte alterations at day 28 after NpCit treatment, longer investigations should be carried out before finally reaching conclusions about the sample's biocompatibility and safeness in biomedical applications for the elderly.

The presence of excessive iron was observed until the 28th day of NpCit treatment in both the elderly group (liver and kidneys) and the young group (spleen, liver, and lungs) as revealed by ICP-OES and histology studies. Grotto ${ }^{49}$ has pointed out that an elevated amount of iron in tissues can damage lipid structures, proteins, and DNA, causing severe tissue damage or mutations. However, as mentioned earlier, signs of structural damage, including necrosis and even inflammation, were never observed throughout the whole study period, despite obvious high concentration of MNPs in some organs. Accordingly, young mice exposed to a bolus dose of dextran-coated magnetite NPs did not show morphological or ultramicroscopic alterations, even when the MNPs were retained for long term (6 months) in the liver and spleen. ${ }^{50}$

It is well established that excessive iron, such as iron coming from metabolized NPs, is gradually deposited in various organs, ${ }^{51,52}$ especially in the spleen and liver, ${ }^{32,53,54}$ corroborating the findings of the present study in both elderly and young animals. However, some differences related to age were found. Although the amount of iron detected in the blood of EC animals was slightly lower than that of YC groups, all the organs (spleen, liver, kidney, lung, and brain) of older mice presented a significantly higher concentration of iron than those of young animals, highlighting an important difference in iron biodistribution related to age.

Furthermore, the elderly and young animals presented a completely different iron biodistribution profile after $\mathrm{NpCit}$ injection. The significantly higher iron concentration in the liver at the 28th day after the injection, relative to their respective controls, was the only similar result between the two animal groups. The difference in iron distribution is another important aspect, because several diseases are associated with alterations in iron metabolism ${ }^{55}$ and should be considered when investigating the biodegradation of iron oxide nanoparticles designed as a diagnostic or therapeutic agent for those diseases, especially in older animals. ${ }^{34}$

In agreement with our results, some literature data have shown that older animals are more susceptible to the adverse effects of nanoparticles than young animals. ${ }^{17}$ Inhalation of $\mathrm{SiO}_{2}$ nanoparticles under identical conditions caused more pulmonary and cardiovascular damage in elderly rats than in young animals. ${ }^{56}$ Aluminum or copper nanoparticles induced higher neurotoxicity in older adult rats than in young adult rats, suggesting that the elderly animals are more vulnerable to brain damage induced by nanoparticles. ${ }^{34}$ Furthermore, aged mice present more intestinal permeability and consequently more NP absorption, and a higher liver deposition and hence more liver injuries, which can culminate in increased oxidative stress and inflammation levels after NP administration. ${ }^{57}$ In spite of the relevance of these data, an extensive search in the literature (Table 5) 
Table 5 Nanoparticle investigations in aged organisms

\begin{tabular}{|c|c|c|c|c|c|c|}
\hline Author & $\begin{array}{l}\text { Nanoparticle } \\
\text { sample }\end{array}$ & Concentration & Exposure time & Organism & $\begin{array}{l}\text { Parameter } \\
\text { studied }\end{array}$ & $\begin{array}{l}\text { Effect } \\
\text { reported }\end{array}$ \\
\hline $\begin{array}{l}\text { Kim et al } \\
(2008)^{58}\end{array}$ & $\begin{array}{l}\text { Pt NP as } \\
\text { antioxidant }\end{array}$ & 0.25 and $0.5 \mathrm{mM}$ & $\begin{array}{l}\text { Organisms } \\
\text { counted every } \\
\text { second day }\end{array}$ & Caenorhabditis elegans & Lifespan & Prolongation \\
\hline $\begin{array}{l}\text { Scharf et al } \\
(2013)^{59}\end{array}$ & Silica NP & ND & ND & Caenorhabditis elegans & Protein homeostasis & $\begin{array}{l}\text { Molecular changes - } \\
\text { premature aging phenotype }\end{array}$ \\
\hline $\begin{array}{l}\text { Zhang et al } \\
(2016)^{60}\end{array}$ & $\begin{array}{l}\mathrm{Fe}_{3} \mathrm{O}_{4} \mathrm{NP} \text { as } \\
\text { antioxidant }\end{array}$ & $200 \mu \mathrm{g} / \mathrm{mL}$ of $\mathrm{NP}$ & Ingestion daily & $\begin{array}{l}\text { Drosophila } \\
\text { melanogaster }\end{array}$ & Lifespan & Prolongation \\
\hline $\begin{array}{l}\text { Chen et al } \\
(2008)^{56}\end{array}$ & $\mathrm{SiO}_{2} \mathrm{NP}$ & $24.1 \mathrm{mg} / \mathrm{m}^{3}$ & $\begin{array}{l}\text { Inhalation } \\
40 \mathrm{~min} / \text { day } \\
\text { for } 4 \text { weeks }\end{array}$ & $\begin{array}{l}\text { Aged and young male } \\
\text { Sprague Dawley rats }\end{array}$ & $\begin{array}{l}\text { Cardiovascular and } \\
\text { pulmonary functions }\end{array}$ & $\begin{array}{l}\text { Decreased in the aged } \\
\text { animals }\end{array}$ \\
\hline $\begin{array}{l}\text { Gaté et al } \\
(2017)^{61}\end{array}$ & $\mathrm{TiO}_{2} \mathrm{NP}$ & $10 \mathrm{mg} / \mathrm{m}^{3}$ & $\begin{array}{l}\text { Inhalation } \\
6 \mathrm{~h} / \text { day, } 5 \text { days/ } \\
\text { week for } 4 \text { weeks }\end{array}$ & Aged and young rats & Biodistribution & $\begin{array}{l}\text { Higher amount of titanium } \\
\text { in spleen and liver of the } \\
\text { aged group }\end{array}$ \\
\hline $\begin{array}{l}\text { Sharma } \\
\text { et al } \\
(2013)^{34}\end{array}$ & $\begin{array}{l}\mathrm{Ag}, \mathrm{Cu} \text {, and } \\
\mathrm{AlNP}\end{array}$ & $\begin{array}{l}50 \mathrm{mg} / \mathrm{kg} \text { different } \\
\text { NP sizes }\end{array}$ & $\begin{array}{l}\text { Once daily for } \\
\text { I week }\end{array}$ & Aged and young rats & Brain damage & $\begin{array}{l}\mathrm{Ag} \text { and } \mathrm{Cu} \text { NPs are more } \\
\text { toxic than AI NPs } \\
\text { Inflammation, neurotoxicity }\end{array}$ \\
\hline $\begin{array}{l}\text { Wei et al } \\
(2016)^{57}\end{array}$ & $\mathrm{ZnO} N \mathrm{NP}$ & $\begin{array}{l}50 \mathrm{mg} / \mathrm{kg} \text { and } \\
300 \mathrm{mg} / \mathrm{kg} \text { of } \\
\mathrm{ZnO} \mathrm{NP}\end{array}$ & $\begin{array}{l}\text { Oral gavage for } \\
2 \text { weeks }\end{array}$ & Aged and young mice & $\begin{array}{l}\text { Biodistribution, } \\
\text { toxicity }\end{array}$ & $\begin{array}{l}\text { Increased hepatotoxicity in } \\
\text { aged mice }\end{array}$ \\
\hline $\begin{array}{l}\text { Shibuya } \\
\text { et al } \\
(2014)^{62}\end{array}$ & $\begin{array}{l}\text { Pd }+ \text { Pt NPs } \\
(P A P L A L) \text { as } \\
\text { antioxidant }\end{array}$ & $200 \mu \mathrm{L} /$ mouse & $\begin{array}{l}\text { Transdermal use } \\
\text { for } 4 \text { weeks, on } \\
\text { the first day of } \\
\text { each week }\end{array}$ & SodI ${ }^{-1-}$ mice & $\begin{array}{l}\text { Aging-like skin } \\
\text { atrophy }\end{array}$ & $\begin{array}{l}\text { Attenuation of skin atrophy } \\
\text { in SOD-deficient mice, } \\
\text { improvement in wound } \\
\text { healing in aged mice }\end{array}$ \\
\hline $\begin{array}{l}\text { Zheng } \\
\text { et al } \\
(20 I 2)^{63}\end{array}$ & Nab-paclitaxel & $100 \mathrm{mg} / \mathrm{m}^{2}$ & $\begin{array}{l}\text { Intravenous (Iv) } \\
\text { weekly }\end{array}$ & $\begin{array}{l}\text { Elderly patients with } \\
\text { lung cancer (stage IV) }\end{array}$ & Toxicity & $\begin{array}{l}\text { Lower toxicity than } \\
\text { paclitaxel, improved } \\
\text { targeting }\end{array}$ \\
\hline $\begin{array}{l}\text { Okuma } \\
\text { et al } \\
(2016)^{64}\end{array}$ & Nab-paclitaxel & $\begin{array}{l}100 \mathrm{mg} / \mathrm{m}^{2}+ \\
\text { carboplatinum }\end{array}$ & $\begin{array}{l}\text { Iv use on days I, } \\
8 \text {, and I5 of each } \\
2 \text { I-day cycle for } \\
\text { up to six cycles }\end{array}$ & $\begin{array}{l}\text { Elderly patients with } \\
\text { lung cancer }\end{array}$ & $\begin{array}{l}\text { Toxicity } \\
\text { Efficacy }\end{array}$ & $\begin{array}{l}\text { Higher toxicity than } \\
\text { carboplatinum alone } \\
\text { Severe adverse effects } \\
\text { Lower survival }\end{array}$ \\
\hline $\begin{array}{l}\text { Valerio } \\
\text { et al } \\
(2017)^{65}\end{array}$ & Nab-paclitaxel & $\begin{array}{l}100 \mathrm{mg} / \mathrm{m}^{2}+ \\
\text { trastuzumab }\end{array}$ & 3 weeks & $\begin{array}{l}\text { Elderly Caucasian } \\
\text { women with breast } \\
\text { cancer }\end{array}$ & Overall survival & Prolongation \\
\hline $\begin{array}{l}\text { Herrera } \\
\text { et al } \\
(2019)^{66}\end{array}$ & Nab-paclitaxel & $\begin{array}{l}\text { Review of clinical } \\
\text { trials }\end{array}$ & Several protocols & $\begin{array}{l}\text { Non-small-cell lung } \\
\text { cancer } \\
\text { Patients } \geq 70 \text { years } \\
\text { (only 15\% in Phase } \\
\text { III trials) }\end{array}$ & $\begin{array}{l}\text { Overall survival } \\
\text { Safety, tolerability }\end{array}$ & $\begin{array}{l}\text { Benefits on survival and } \\
\text { toxicity effects }\end{array}$ \\
\hline
\end{tabular}

Abbreviations: Nab, nanoparticle-albumin-bound; NP, nanoparticle; ND, not determined.

concerning the administration of nanomaterials in older organisms and its effects reveals a huge gap in the area. Investigations have been performed in classical aging models such as Caenorhabditis elegans ${ }^{58,59}$ and Drosophila melanogaster,${ }^{60}$ and rats ${ }^{61}$ which showed opposite effects of NPs, and in animals deficient for antioxidant enzymes, ${ }^{62}$ due to their similarities with aged organisms. Certainly, more information concerning nanotoxicity and biodistribution may come from the data obtained from aged patients treated with nanomaterials. ${ }^{63-65}$ In a recent review of patients with lung cancer treated with nanoparticles, Herrera et $a^{16}$ included data related to the safety and tolerability of nanomaterials, while highlighting the underrepresentation of elderly patients in the clinical trials.

Despite all the age-dependent effects observed in the present study, it is important to remember that the investigated elderly animals did not present any histological alterations or the clinical characteristics of old mice, thus evidencing they were in good health. Certainly, studies focusing on the safety of iron-based MNPs for animals bearing chronic diseases are mandatory for a better understanding of the effects of nanostructured materials on older organisms. 


\section{Conclusion}

The NpCit sample induced age-dependent effects on mice. In the young animals, it caused very slight and temporary biochemical and hematological changes, such as changes in albumin and urea levels and HGB parameters. The changes associated with the natural aging process were more numerous and profound in the elderly than those induced by NpCit in the young animals. These aging changes made the elderly mice susceptible to NpCit effects that were either synergistic (leukocytes) or opposite (erythrocytes, albumin, TNF- $\alpha$, and NO levels) to the aging changes and sometimes more durable (leukocytes). Iron distribution was also age dependent and showed different patterns until the 28th day of treatment. Remarkably, no significant changes were seen in the clinical studies or in the histological features after the treatment, indicating the biocompatibility of $\mathrm{NpCit}$ and its potential use in biomedical applications. However, the differences in data concerning the biodistribution and biocompatibility of nanoparticles between elderly and young animals emphasize the need for more studies performed for a longer time window to appropriately extend the benefits of nanotechnology to the elderly population.

\section{Acknowledgments}

We acknowledge Dr Emilia CO Lima from the Federal University of Goiás, Goiânia, GO, Brazil, for providing the NpCit sample, the Coordination for Further Training of Graduate Staff(CAPES), the Brazilian National Council for Technological and Scientific Development (CNPq), the Foundation to Support Research in the Federal District (FAPDF), the Network of Nanobiotechnology CON-NANO (CAPES), the National Institute of Science and Technology in Nanobiotechnology (INCT-Nanobiotecnologia), the Center for Nanoscience and Nanobiotechnology of the University of Brasilia (CNANOUnB), and the Dean of Research and Post-Graduation of the University of Brasília (DPP-UnB) for financial support.

\section{Disclosure}

The authors report no conflicts of interest in this work.

\section{References}

1. Mohammadi Z, Zack MS, Seidi K, Barati M, Akbarzadeh A, Zarghami N. The effect of chrysin loaded PLGA-PEG on metalloproteinase gene expression in mouse 4T1 tumor model. Drug Res (Stuttg). 2017;67(4): 211-216. doi: $10.1055 / \mathrm{s}-0042-122136$

2. Haley B, Frenkel E. Nanoparticles for drug delivery in cancer treatment. Urol Oncol Semin Orig Investig. 2008;26:57-64. doi:10.1016/j. urolonc.2007.03.015

3. Steichen SD, Caldorera-Moore M, Peppas NA. A review of current nanoparticle and targeting moieties for the delivery of cancer therapeutics. Eur J Pharm Sci. 2013;48(3):416-427. doi:10.1016/j.ejps.2012. 12.006
4. Kossatz S, Grandke J, Couleaud P, et al. Efficient treatment of breast cancer xenografts with multifunctionalized iron oxide nanoparticles combining magnetic hyperthermia and anti-cancer drug delivery. Breast Cancer Res. 2015;17(1):1-17. doi:10.1186/s13058-014-0509-4

5. Cassim SM, Giustini AJ, Baker I, et al. Development of novel magnetic nanoparticles for hyperthermia cancer therapy. Proc SPIE Int Soc Opt Eng. 2011;7901:790115.

6. Buske N, Sonntag H, Götze T. Magnetic fluids - their preparation, stabilization and applications in colloid science. Colloids and Surfaces. 1984;12:195-202. doi:10.1016/0166-6622(84)80099-2

7. Lacava LM, Lacava ZGM, Azevedo RB, et al. Use of magnetic resonance to study biodistribution of dextran-coated magnetic fluid intravenously administered in mice. J Magn Magn Mater. 2002;252:367-369. doi:10.1016/S0304-8853(02)00654-6

8. Chaves SB, Lacava LM, Lacava ZGM, et al. Light microscopy and magnetic resonance characterization of a DMSA-coated magnetic fluid in mice. IEEE Trans Magn. 2002;38(5):3231-3233. doi:10.1109/ TMAG.2002.802495

9. Sadeghiani N, Barbosa LS, Guedes MHA, et al. Magnetic resonance of polyaspartic acid-coated magnetite nanoparticles administered in mice. IEEE Trans Magn. 2005;41(10):4108-4110. doi:10.1109/TMAG. 2005.855334

10. Lacava ZGM, Azevedo RB, Martins EV, et al. Biological effects of magnetic fluids: toxicity studies. J Magn Magn Mater. 1999;201:431-434. doi:10.1016/S0304-8853(99)00002-5

11. Ivkov R. Magnetic nanoparticle hyperthermia: A new frontier in biology and medicine? Int J Hyperthermia . 2013;6736(8):703-705. doi:10.310 9/02656736.2013.857434

12. Candido NM, Calmon MF, Taboga SR, et al. High efficacy in hyperthermia-associated with polyphosphate magnetic nanoparticles for oral cancer treatment. J Nanomed Nanotechnol. 2014;05(03):1-11.

13. Wu W, Jiang CZ, Roy VAL. Designed synthesis and surface engineering strategies of magnetic iron oxide nanoparticles for biomedical applications. Nanoscale. 2016;8(47):19421-19474. doi:10.1039/c6nr07542h

14. Sheedfar F, Biase SD, Koonen D, et al. Liver diseases and aging: friends or foes? Aging Cell. 2013;12(6):950-954. doi:10.1111/acel.12128

15. Hasty P, Vijg J. Genomic priorities in aging. Science. 2002;296(5571): 1250-1251. doi:10.1126/science. 1071808

16. Jenkins EO, Deal AM, Anders CK, et al. Age-specific changes in intrinsic breast cancer subtypes: a focus on older women. Oncologist. 2014;19(10):1076-1083. doi:10.1634/theoncologist.2014-0184

17. Li Y, Zhang Y, Yan B. Nanotoxicity overview: Nano-threat to susceptible populations. Int J Mol Sci. 2014;15(3):3671-3697. doi:10.3390/ ijms15033671

18. Calero M, Chiappi M, Lazaro-Carrillo A, et al. Characterization of interaction of magnetic nanoparticles with breast cancer cells. J Nanobiotechnology. 2015;13(1):1-15. doi:10.1186/s12951-014-0062-4

19. Kaur P, Aliru ML, Chadha AS, et al. Hyperthermia using nanoparticles promises and pitfalls punit. Int J Hyperthermia. 2016;32(1):76-88. doi: $10.3109 / 02656736.2015 .1120889$

20. Orucevic A. Breast cancer in elderly caucasian women - an institutionbased study of correlation between breast cancer prognostic markers, tnm stage, and overall survival. Cancers (Basel). 2015;7(3):1472-1483. doi: $10.3390 /$ cancers 7030846

21. Shrestha S, Jiang P, Sousa MH, et al. Citrate-capped iron oxide nanoparticles impair the osteogenic differentiation potential of rat mesenchymal stem cells. J Mater Chem B. 2016;4(2):245-256. doi:10.1039/C5TB02007G

22. Morais PC, Santos RL, Pimenta ACM, et al. Preparation and characterization of ultra-stable biocompatible magnetic fluids using citrate-coated cobalt ferrite nanoparticles. Thin Solid Films. 2006;515(1):266-270. doi:10.1016/j.tsf.2005.12.079

23. Silva AC, Oliveira TR, Mamani JB, et al. Magnetohyperthermia for treatment of gliomas: experimental and clinical studies. Einstein. 2010;8(3):361-367. doi:10.1590/S1679-45082010RW1757

24. Whitehead JC, Hildebrand BA, Sun M, et al. A clinical frailty index in aging mice: comparisons with frailty index data in humans. $J$ Gerontol A Biol Sci Med Sci. 2014;69(6):621-632. doi:10.1093/gerona/glt136 
25. Kückelhaus S, Tedesco AC, Oliveira DM, et al. Optical emission spectroscopy as a tool for the biodistribution investigation of cobalt-ferrite nanoparticles in mice. J Appl Phys. 2005;97(10):2003-2006. doi:10. $1063 / 1.1852311$

26. Sousa MH, Geraldo J, Depeyrot J, et al. Chemical analysis of sizetailored magnetic colloids using slurry nebulization in ICP-OES. Microchem J. 2011;97(2):182-187. doi:10.1016/j.microc.2010.09.002

27. Szigeti K, Hegedus N, Racz K, et al. Thallium labeled citrate-coated prussian blue nanoparticles as potential imaging agent. Contrast Media Mol Imaging. 2018;(4):1-10. doi:10.1155/2018/2023604

28. Kückelhaus S, Garcia VAP, Lacava LM, et al. Biological Investigation of a citrate-coated cobalt-ferrite-based magnetic fluid. J Appl Phys. 2003;93(10):6707-6708. doi:10.1063/1.1558665

29. Bonadio RS, Arcanjo AC, Lima ECD, et al. DNA methylation alterations induced by transient exposure of MCF-7 cells to maghemite nanoparticles. Nanomedicine. 2017;12(23):2637-2649. doi:10.2217/ nnm-2017-0241

30. Neves WP, Sousa CRS, Miranda-Vilela AL, et al. Comparative efficacy of a biocompatible citrate-functionalized magnetic fluid mediating radiofrequency hhyperthermia and magnetohyperthermia to treat ectopic ehrlichsolid-tumor-bearing elderly mice. J Cancer Sci Ther. 2017;9:392-393.

31. Pernodet N, Fang X, Sun Y, et al. Adverse effects of citrate/gold nanoparticles on human dermal fibroblasts. Small. 2006;2(6):766-773. doi:10.1002/smll.200500492

32. Sharma A, Cornejo C, Mihalic J, et al. Physical characterization and in vivo organ distribution of coated iron oxide nanoparticle. Sci Rep. 2018;8(1):4916. doi:10.1038/s41598-018-23317-2

33. Feng Q, Liu Y, Huang J, Chen K, Huang J, Xiao K. Uptake, distribution, clearance, and toxicity of iron oxide nanoparticles with different sizes and coatings. Sci Rep. 2018;8(1):1-13. doi:10.1038/ s41598-017-17765-5

34. Sharma A, Muresanu DF, Patnaik R, et al. Size- and age-dependent neurotoxicity of engineered metal nanoparticles in rats. Mol Neurobiol. 2013;48(2):386-396. doi:10.1007/s12035-013-8500-0

35. Lee WM. Acute liver failure in the United States. Semin Liver Dis. 2003;23(3):217-226. doi:10.1055/s-2003-42641

36. Sutherland RJ. Biochemical evaluation of the hepatobiliary system in dogs and cats. Vet Clin North Am Small Anim Pract. 1989;19(5):899-927.

37. Quimby FW, Luong HR. Clinical chemistry of the laboratory mouse. In: Fox JG, Barthold SW, Davisson MT, Newcomer CE, Quimby FW, Smith AL, editors. The Mouse in Biomedical Research: Normative Biology, Husbandry, and Models. California: Elsevier; 2007:171-216.

38. Dewar HA, Rowell NR, Smith AJ. Serum glutamic oxalacetic transaminase in acute myocardial infarction. Br Med J. 1958;2(5105):1121-1125.

39. Bruce R, Todd JK, Ledune L. Serum transaminase: its clinical use in diagnosis and prognosis. Br Med J. 1958;2(5105):1125-1128.

40. Almiersjo O, Bengnmark S, Engevik L, et al. Serum enzyme changes after hepatic dearterialization in man. Ann Surg. 1968;167:9-17. doi:10.1097/00000658-196801000-00002

41. Chalifoux A, Lagacé A. Enzymes sériques pour le diagnostic de la nécrose hépatique aigue expérimentale. Can J Comp Med. 1969;33(3): 178-186.

42. Thrall MA, Baker DC, Campbell TW, et al. Hematologia e Bioquímica Clínica Veterinária. Roca, São Paulo. 2007:259-260.

43. Pulchinelli Junior A, Junior AJC, Gimenes AC. Clinical laboratory findings in the elderly. J Bras Patol Med Lab. 2012;48(3):169-174. doi:10.1590/S1676-24442012000300004

44. Farrugia A. Albumin usage in clinical medicine: tradition or therapeutic? Transfus Med Rev. 2010;24(1):53-63. doi:10.1016/j.tmrv.2009.09.005

45. Li J, Gárcia CC, Riedt T, et al. Murine hematopoietic stem cell reconstitution potential is maintained by osteopontin during aging. Sci Rep. 2018;8(1):1-9.

46. Ames BN, Shigenaga MK, Hagen TM. Oxidants, antioxidants, and the degenerative diseases of aging. Proc Natl Acad Sci US A. 1993;90(17): 7915-7922.

47. Ewers I, Rizzo LV, Filho JK. Imunologia e envelhecimento. Einstein. 2008;6(Supl 1):13-20.
48. Habib S, Ali A. Biochemistry of nitric oxide. Indian J Clin Biochem. 2011;26(1):3-17. doi:10.1007/s12291-011-0108-4

49. Grotto HZW. Fisiologia e metabolismo do ferro. Rev Bras Hematol Hemoter. 2010;32(2):8-17. doi:10.1590/S1516-84842010005000050

50. Estevanato L, Cintra D, Baldini N, et al. Preliminary biocompatibility investigation of magnetic albumin nanosphere designed as a potential versatile drug delivery system. Int J Nanomedicine. 2011;6:1709-1717. doi:10.2147/IJN.S21323

51. Nallathamby PD, Mortensen NP, Palko HA, et al. New surface radiolabeling schemes of super paramagnetic iron oxide nanoparticles (SPIONs) for biodistribution studies. Nanoscale. 2015;7(15):6545-6555. doi:10.1039/C4NR06441K

52. Han X, Yao P, Cheng $C$, et al. Preparation and in vivo biodistribution of ultra-small superparamagnetic iron oxide nanoparticles with high magnetic targeting response. J Nanosci Nanotechnol. 2018;18(2):879-886. doi:10.1166/jnn.2018.14110

53. Cançado RD. Sobrecarga e quelação de ferro na anemia falciforme. Rev Bras Hematol Hemoter. 2007;29(3):316-326. doi:10.1590/ S1516-84842007000300025

54. Rodrigues D, Freitas M, Costa VM, et al. Quantitative histochemistry for macrophage biodistribution on mice liver and spleen after the administration of a pharmacological-relevant dose of polyacrylic acidcoated iron oxide nanoparticles. Nanotoxicology. 2017;11(2):256-266. doi:10.1080/17435390.2017.1291865

55. Crielaard BJ, Lammers T, Rivella S. Targeting iron metabolism in drug discovery and delivery. Nat Rev Drug Discov. 2017;16(6):400-423. doi: $10.1038 /$ nrd.2016.248

56. Chen Z, Meng H, Xing G, et al. Age-related differences in pulmonary and cardiovascular responses to $\mathrm{SiO} 2$ nanoparticle inhalation: nanotoxicity has susceptible population. Environ Sci Technol. 2008;42(23): 8985-8992.

57. Wei Y, Li Y, Jia J, et al. Aggravated hepatotoxicity occurs in aged mice but not in young mice after oral exposure to zinc oxide nanoparticles. NanoImpact. 2016;3-4:1-11. doi:10.1016/j.impact.2016.09.003

58. Kim J, Takahashi M, Shimizu T, et al. Effects of potent antioxidant, platinum nanoparticle, on the lifespan of Caenorhabditis elegans. Mech Ageing Dev. 2008;129(6):322-331.

59. Scharf A, Piechulek A, von Mikecz A. Effect of nanoparticles on the biochemical and behavioral aging phenotype of the nematode caenorhabditis elegans. ACS Nano. 2013;7(12):10695-10703. doi:10.1021/ nn403443r

60. Zhang Y, Wang Z, Li X, et al. Dietary Iron Oxide Nanoparticles Delay Aging and Ameliorate Neurodegeneration in Drosophila. Adv Mater. 2016;28(7):1387-1393. doi:10.1002/adma.201503893

61. Gaté L, Disdier C, Cosnier F, et al. Biopersistence and translocation to extrapulmonary organs of titanium dioxide nanoparticles after subacute inhalation exposure to aerosol in adult and elderly rats. Toxicol. 2017; 265:61-69.

62. Shibuya S, Ozawa Y, Watanabe K, et al. Palladium and platinum nanoparticles attenuate aging-like skin atrophy via antioxidant activity in mice. PLoS One. 2014;9(10):1-9. doi:10.1371/journal.pone.0109288

63. Zheng Q, Yao Y, Nan K. Weekly intravenous nanoparticle albuminbound paclitaxel for elderly patients with stage IV non-small-cell lung cancer: a series of 20 cases. J Biomed Res. 2012;26(3):159-164. doi:10.7555/JBR.26.20110106

64. Okuma Y, Hosomi Y, Takahashi S, et al. A phase II study of nanoparticle albumin-bound paclitaxel plus carboplatin as the first-line therapy in elderly patients with previously untreated advanced non small cell lung cancer. Cancer Chemother Pharmacol. 2016;78(2):383-388. doi:10. 1007/s00280-016-3092-9

65. Valerio MR, Ancona C, Marchese A, et al. Impressive objective response to nab-paclitaxel plus trastuzumab as fifth line therapy in an elderly HER-2 positive breast cancer patient. J Cancer Ther. 2017;08(11):933-994.

66. Herrera DA, Ashai N, Perez-Soler R, et al. Nanoparticle albumin boundpaclitaxel for treatment of advanced non-small cell lung cancer: an evaluation of the clinical evidence. Expert Opin Pharmacother. 2019; 20(1):95-102. doi:10.1080/14656566.2018.1546290 


\section{Supplementary material}

Table SI Summary of effects of aging and/or NpCit treatment in mice

\begin{tabular}{|c|c|c|c|}
\hline Effects & Effects of aging & $\begin{array}{l}\text { Effects of NpCit treatment on } \\
\text { elderly mice }\end{array}$ & $\begin{array}{l}\text { Effects of } \mathrm{NpCit} \text { treatment } \\
\text { on young mice }\end{array}$ \\
\hline $\begin{array}{l}\text { How the effects were } \\
\text { checked }\end{array}$ & $\begin{array}{l}\text { Elderly control }(E C) \text { in comparison } \\
\text { to young control }(\mathrm{YC})\end{array}$ & $\begin{array}{l}\text { NpCit treated elderly (EI, E7, and E28) } \\
\text { in comparison to elderly control (EC) }\end{array}$ & $\begin{array}{l}\mathrm{NpCit} \text { treated young }(\mathrm{YI}, \mathrm{Y} 7 \text {, } \\
\text { and } \mathrm{Y} 28 \text { ) in comparison to } \\
\text { young control (YC) }\end{array}$ \\
\hline Clinical effects & Not detected & Not detected & Not detected \\
\hline Biochemical & $\begin{array}{l}\text { ALT: } \mathrm{EC}<\mathrm{YC} \\
\text { Albumin: } \mathrm{EC}<\mathrm{YC}\end{array}$ & $\begin{array}{l}\text { Urea: } \mathrm{EI}<\mathrm{EC} \\
\text { Albumin: } \mathrm{EI}>\mathrm{EC}\end{array}$ & $\begin{array}{l}\text { Urea: } \mathrm{Y} 7<\mathrm{YC} \\
\text { Albumin: } \mathrm{Y} 7<\mathrm{YC}\end{array}$ \\
\hline Leukocytes & $\begin{array}{l}\text { Lymphocytes: } E C<Y C \\
\text { Myeloid cells: } E C>Y C\end{array}$ & $\begin{array}{l}\text { Lymphocytes: } \mathrm{EI}<\mathrm{EC} \text { and } \mathrm{E} 28<\mathrm{EC} \\
\text { Myeloid cells: } \mathrm{EI}>\mathrm{EC} \text { and } \mathrm{E} 28>\mathrm{EC}\end{array}$ & Not detected \\
\hline Platelet cells & Not detected & Not detected & Y7>YC \\
\hline Erythrocytes & $\begin{array}{l}\text { HGB: } E C<Y C \\
\text { HCT: } E C<Y C \\
M C V: E C>Y C \\
M C H: E C>Y C \\
\text { RDW-CV: EC }>Y C\end{array}$ & Not detected & MCH: YI>YC \\
\hline TNF- $\alpha$ levels & & $\mathrm{E} 7<\mathrm{EC}$ & Not detected \\
\hline NO levels & $\mathrm{EC}<\mathrm{YC}$ & Not detected & $\mathrm{YI}<\mathrm{Y7}$ \\
\hline Histological alterations & Not detected & Not detected & Not detected \\
\hline Iron biodistribution & $\begin{array}{l}\text { Spleen: } E C>Y C \\
\text { Liver: } E C>Y C \\
\text { Lung: } E C>Y C \\
\text { Kidney: } E C>Y C \\
\text { Brain: } E C>Y C\end{array}$ & $\begin{array}{l}\text { Blood: } \mathrm{EI}>\mathrm{EC} \\
\text { Liver: } \mathrm{E} 28>\mathrm{EC} \\
\text { Kidney: } \mathrm{EI}>\mathrm{EC} \text { and } \mathrm{E} 28>\mathrm{EC}\end{array}$ & $\begin{array}{l}\text { Spleen: } Y 28>Y C \\
\text { Liver: } Y 28>Y C \\
\text { Lung: } Y 1>Y C \text { and } Y 28>Y C \\
\text { Brain: } Y 7>Y C\end{array}$ \\
\hline
\end{tabular}

Abbreviations: NpCit, nanoparticles coated with citrate; TNF- $\alpha$, tumor necrosis factor alpha; EC, elderly control; EI, E7, and E28, elderly treated groups at day 0I, day 07 , and day 28, respectively; YC, young control; YI, Y7, and Y28, young treated groups at day 01 , day 07 , and day 28 , respectively; $>$, means significantly higher than; <, means significantly lower than; ALT, alanine aminotransferase; HGB, hemoglobin; HCT, hematocrit; MCV, mean corpuscular volume; MCH, mean corpuscular hemoglobin; RDW-CV, red blood cell distribution width as coefficient of variation; NO, nitric oxide.

International Journal of Nanomedicine

\section{Publish your work in this journal}

The International Journal of Nanomedicine is an international, peerreviewed journal focusing on the application of nanotechnology in diagnostics, therapeutics, and drug delivery systems throughout the biomedical field. This journal is indexed on PubMed Central,

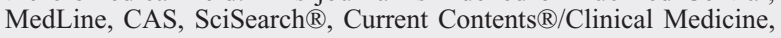

\section{Dovepress}

Journal Citation Reports/Science Edition, EMBase, Scopus and the Elsevier Bibliographic databases. The manuscript management system is completely online and includes a very quick and fair peer-review system, which is all easy to use. Visit http://www.dovepress.com/ testimonials.php to read real quotes from published authors. 